\title{
One text, two varieties of German: fruitful directions for multilingual humour in "translation"
}

\author{
Mary Catherine Frank
}

Freelance translator \& researcher mf1876@my.bristol.ac.uk

\begin{abstract}
A heterolingual text is characterised by the presence of two or more different languages, or two or more varieties of the same language (Corrius \& Zabalbeascoa 2011: 115). This article discusses possible methods of translating into English of a text containing two varieties of German: Ottokar Domma's Der brave Schüler Ottokar /The Good Schoolboy Ottokar]. In these stories, about a schoolboy growing up in the German Democratic Republic (GDR) in the 1960s, Domma creates a zone of friction between child narrator Ottokar's everyday German and the language of GDR officialdom ("official discourse"). This article first shows that following a conventional method of translating a literary text into English does not allow this satire to be conveyed to the reader. It then presents two alternative translational methods — "thick" and creative — that demonstrate how it is helpful, indeed in some cases necessary, for the translator to adopt a broad understanding of "translation" in respect of texts that exploit multilingualism for humorous purposes. It is argued that methods of translating in which effect is privileged over form - which here included introducing multimodality - can serve well to open up heterolingual humour for speakers of other languages.
\end{abstract}

Keywords: official discourse, satire, "thick" translation, creative translation, multimodality.

\section{Introduction}

The stories about schoolboy Ottokar began appearing in Eulenspiegel, the GDR's weekly satirical magazine, in 1962. The first collection of 29 stories was published in 1967 as Der brave Schüler Ottokar [The Good Schoolboy Ottokar]. In total, 19 collections were published, some after the demise of the GDR in 1990. This article focuses on the translation of the first collection.

The Ottokar stories were written by Otto Häuser, who from the late 1950s was an education correspondent at Neues Deutschland [New Germany], the official newspaper of the 
ruling SED party. They were published under the pen name Ottokar Domma, and this article will refer to the author by this name. His eponymous character is 12 years old and lives in a semi-rural location in the GDR. Ottokar narrates his life at home and at school. His astute observations of adults' foibles and weaknesses, and his adventures (such as incurring the wrath of an elderly lady while travelling by train), are typical of mischievous schoolboy characters in many different national contexts. What distinguishes Ottokar is his heterolinguality. As well as using the language of an ordinary GDR schoolboy, his faux-naïve narrative appropriates, manipulates and mis-represents a second variety of German for satirical effect. This article illustrates this heterolinguality, discusses how it creates humour, demonstrates its challenges for the translator in a conventional Anglophone literary translation context and offers two possible alternative methods for translating it into English. These approaches demonstrate that a broad conceptualisation of "translation" can serve well to open up heterolingual humorous texts for speakers of other languages.

\section{Official discourse, a second variety of German in the GDR}

The second variety of German that Ottokar intermingles with his everyday German is that of officialdom. It is extremely common everywhere for political parties to constantly repeat certain words, phrases and themes designed to convey key objectives and values. This strategy was adopted quite purposefully in the GDR, where the SED relentlessly employed distinctive themes and linguistic devices to articulate "control, order, rationality, consistency, and conviction" (Stevenson 2002: 59). These themes and devices constituted, in effect, a language variety different from either everyday German or ordinary political terminology (Stevenson 2002: 55). This variety of German will here be termed "official discourse." Its key characteristics are listed in Table 1.

Table 1. Linguistic and thematic characteristics of official discourse (sources: Bergmann 1996; Rodden 2002; Schiewe \& Schiewe 2000; Stevenson 2002; Wolle 2001; Young 1991)

\begin{tabular}{|l|}
\hline \multicolumn{1}{|c|}{ Linguistic devices } \\
\hline Repetition/redundancy \\
\hline Anaphora \\
\hline Hyperbole \\
\hline Naming of self and others \\
\hline Neologisms \\
\hline Elevated vocabulary \\
\hline Old-fashioned word order \\
\hline Slogans and catchphrases \\
\hline Formulaic phrases/clichés \\
\hline Metaphor, especially the metaphor of struggle \\
\hline Emphatic adjectives and adverbs \\
\hline Words that convey collective identity \\
\hline Foreign words \\
\hline Russian loanwords \\
\hline Euphemisms \\
\hline Aphorisms \\
\hline Fixed collocations \\
\hline
\end{tabular}




\begin{tabular}{|l|}
\multicolumn{1}{|c|}{ Themes } \\
\hline The domination of science/scientific atheism \\
\hline Brotherly collaboration \\
\hline The evils of capitalism \\
\hline The glorification of labour \\
\hline Cleanliness, virtue, order and safety \\
\hline
\end{tabular}

The first five items on the list of devices of GDR officialdom are also commonly found in children's literature. By incorporating such devices into its own discourse, the SED was placing the populace in a child-like position in relation to the structures of power. Indeed, this overlap between children's literature and official discourse may have motivated Domma to use this genre as a "cloak" for his satire. More broadly, multilingual humour arises in the Ottokar stories from the incongruous interplay between the entire range of characteristics of official discourse and Ottokar's everyday German. It is the presence of official discourse in Ottokar's German that makes these stories a heterolingual text. While such a text might generally be thought to contain two or more distinct, independent languages, heterolinguality should be conceptualised more broadly as also embracing "an instance of relevant language variation, sufficient to signal more than one identifiable speech community being portrayed or represented within a text" (Corrius \& Zabalbeascoa 2011: 115).

Despite their superficial presentation as harmlessly amusing children's tales, the Ottokar stories were originally published in a satirical magazine aimed at adults. Their heterolinguality does not simply reflect a child's normal experimentation with language and its accompanying mistakes. In fact, Domma deliberately creates a zone of friction between the two varieties of German used by Ottokar. In this way, he exposes the pomposity, redundancy and emptiness of official discourse and punctures it to satirise those who used it unthinkingly. This will be illustrated through Ottokar's treatment of proper names.

\section{Multilingual humour: the clash between official discourse and everyday German}

Ottokar is fascinated by names. The first story in the collection is dedicated to this subject, and the titles of many of the subsequent stories highlight a named individual: Unser Herr Pionierleiter Alfons [Our Herr Pioneer Leader Alfons], Der verkannte Herr Burschelmann [How we Misunderstood Herr Burschelmann], Mein Freund Aljoscha [My Friend Aljoscha] and so on. In official discourse, prominent public figures were routinely identified by their elaborate full job titles (the "naming of self and others" noted in Table 1). SED First Secretary Walter Ulbricht, for example, was referred to as Der Vorsitzende des Staatsrates und Erster Sekretär des Zentralkomitees der Sozialistischen Einheitspartei Deutschlands Walter Ulbricht [The Chairman of the State Council and First Secretary of the Central Committee of the Socialist Unity Party of Germany Walter Ulbricht]. In Example 1, the opening sentence of a report in the newspaper Berliner Zeitung uses job titles to such excess that it runs to almost 100 words and is extremely difficult to follow.

\section{Example 1}

Zum neuen Jahr übermittelten der Erste Sekretär des Zentralkomitees der KPdSU und Vorsitzende des Ministerrates der UdSSR, N. S. Chruschtschow, und der Vorsitzende des Präsidiums des Obersten Sowjets der UdSSR, L. I. Breshnew, an den Ersten Sekretär des Zentralkomitees der Sozialistischen Einheitspartei Deutschlands und 
Vorsitzenden des Staatsrates der Deutschen Demokratischen Republik. Walter Ulbricht, an den Vorsitzenden des Ministerrates der DDR, Otto Grotewohl, an den Präsidenten der Volkskammer der DDR, Dr. Johannes Dieckmann, sowie an den Präsidenten des Nationalrates der Nationalen Front des demokratischen Deutschland, Prof. Dr. Dr. h. c. Erich Correns folgendes Glückwunschtelegramm.

(January 1, 1963: 1)

[On the occasion of the New Year, the First Secretary of the Central Committee of the Communist Party of the Soviet Union, N.S. Khrushchev, and the Chairman of the Presidium of the Supreme Soviet of the Soviet Union, L.I. Brezhnev, sent to the First Secretary of the Central Committee of the Socialist Unity Party of Germany and Chairman of the State Council of the German Democratic Republic, Walter Ulbricht, to the Chairman of the Council of Ministers of the GDR, Otto Grotewohl, to the President of the People's Chamber of the GDR, Dr Johannes Dieckmann, and to the President of the National Council of the National Front of Democratic Germany, Professor Dr Honorary Dr Erich Correns, the following greetings telegram.]

Ottokar's use of the formal terms Vater [father] and Mutter [mother] satirises this excessive use of elaborate job titles in official discourse, since it would be more natural for him to call his parents Vati or Papa [daddy/dad] and Mutti or Mama [mummy/mum]. An even stronger echo of the excessively formal treatment of proper names in official contexts is the fact that Ottokar almost always refers to his closest friend as mein Freund Harald [my friend Harald], rather than just Harald. This is not simply a child's normal "claiming" of a best friend. When a "job title" is accorded to a child, it becomes a satirical inversion of official discourse.

Furthermore, the phrase mein Freund Harald occurs so frequently that it mimics the repetition, redundancy and anaphora of official discourse. Example 2 shows excerpts from a speech by Friedrich Ebert, a member of the ruling Politbüro, published in Neues Deutschland. Ebert returns repeatedly to the motif of the umfassende[r] Aufbau der Sozialismus [comprehensive construction of socialism].

\section{Example 2}

Mit diesem Gruß verbunden ist unser aufrichtiger Dank für die hervorragenden Leistungen, die unsere werktätigen Frauen und Mädchen beim umfassenden Aufbau des Sozialismus geleistet haben.

[This greeting comes with our deepest thanks for the excellent contributions that our working women and girls have made to the comprehensive construction of socialism.]

Der Vertrag gibt den Bürgern der DDR beim umfassenden Aufbau des Sozialismus Schutz und Sicherheit.

[The treaty gives the citizens of the GDR protection and security for the comprehensive construction of socialism.]

Das ist auch einer der Gründe, die es notwendig machten, ein Programm für die sozialistische Bildung und Erziehung der Menschen in der Periode des umfassenden und vollständigen Aufbaues des Sozialismus auszuarbeiten.

[That is also one of the reasons why it was necessary to develop a programme for the socialist training and education of people during the period of the comprehensive and complete construction of socialism.] 
Schreiten wir gemeinsam und entschlossen mit allen in der Nationalen Front des demokratischen Deutschland vereinten Kräften auf diesem Wege vorwärts in dem Bewußtsein, daß der vollständige und umfassende Aufbau des Sozialismus in der Deutschen Demokratischen Republik eine grundlegende Bedingung für die Lösung der nationalen Frage in Deutschland ist.

(June 27, 1964: 1)

[Let us stride onwards together and determinedly with all the powers that come together in the National Front of democratic Germany in the knowledge that the complete and comprehensive construction of socialism in the German Democratic Republic is a fundamental requirement for resolving the national question in Germany.]

Anaphora also featured prominently in the promise that GDR teenagers made at the Jugendweihe [Youth Consecration] ceremony. The excerpts in Example 3 show the repetition in this promise of Seid Ihr bereit? [Are you willing?] and Ja, das geloben wir! [Yes, we promise this!].

\section{Example 3}

Liebe junge Freunde!

[Dear young friends]

Seid Ihr bereit, für ein glückliches Leben der werktätigen Menschen und ihren Fortschritt in Wirtschaft, Wissenschaft und Kunst zu wirken?

[Are you willing to work for a happy life for working people and their progress in the economy, science and the arts?]

\section{Ja, das geloben wir!}

[Yes, we promise this!]

Seid Ihr bereit, für ein einheitliches, friedliebendes, demokratisches und unabhängiges Deutschland mit Eurem ganzen Wissen und Können einzutreten?

[Are you willing to enlist for a unified, peace-loving, democratic and independent German with your whole mind and ability?]

\section{Ja, das geloben wir! \\ [Yes, we promise this!]}

Seid Ihr bereit, im Geiste der Völkerfreundschaft zu leben und restlos Eure Kräfte einzusetzen, um gemeinsam mit allen friedliebenden Menschen den Frieden zu verteidigen und zu sichern?

[Are you willing to live in the spirit of friendship between peoples and to tirelessly use your resources to work with all peace-loving people to defend and secure peace?]

\section{Ja, das geloben wir!}

[Yes, we promise this!]

In this context, Ottokar's relentless repetition of mein Freund Harald is not coincidental. It appears five times in the story Was ein Knabe alles werden kann [All the Things a Boy can Become], including in consecutive sentences where, in the second instance, switching to the pronoun would be more natural in ordinary speech: 
Mein Freund Harald war ein Wunderbeet und erzeugte fortwährend unterm Hemd oder hinter der Hose mächtige Blumensträuße. Ich sagte zu meinem Freund Harald, das beste ist, wir werden Zauberer.

[My friend Harald was a magic flowerbed and kept producing huge bunches of flowers from under his shirt or behind his trousers. I said to my friend Harald that the best thing would be for us to become magicians.]

Mein Freund Harald also acts as a fixed collocation, again a satirical inversion of the use of this technique in official discourse. Perhaps the most pervasive fixed collocation was Frieden und Sozialismus [peace and socialism], which appeared over 150 times in Neues Deutschland in 1963 alone. Further examples include einheitlich handelnd [working together], sozialistiche Menschengemeinschaft [socialist people's community], allseitige Stärkung [comprehensive strengthening] and the motif noted above, umfassende[r] Aufbau der Sozialismus.

Ottokar adds job titles to many other proper names, from Herr Gemeinderat Kiebitz [Herr Local Councillor Kiebitz] to Herr Mittelstufenlehrer Burschelmann [Herr Middle Grade Teacher Burschelmann]. The effect is greater than mild amusement. This construction is used so extensively and incongruously that it becomes ridiculous, exactly the satirising effect Domma wishes to achieve. This is especially the case when "job titles" are used for young men who have no formal qualifications or authority, such as Herr Landwirtschaftslehrling Albin Knautschke [Herr Agricultural Apprentice Albin Knautschke], or to describe a down-to-earth activity, as with Herr Rucksackbulle Max Speckmann [Herr Bull-in-a-Rucksack Max Speckmann], the village artificial inseminator. Ottokar's misassignment of job titles reaches its most excessive and satirical when a job title becomes a name itself. His friend Heinz Pilgrim is always known by the nickname Pillenheini [PillyHeini] because his father is the village pharmacist, while Siegfried Kugler, another friend, is known as Schweine-Sigi [Piggy-Sigi] because his father runs the village pig farm.

Similarly, Ottokar's persistent use of the possessive adjective unser [e] [our] in conjunction with proper names is a satirical inversion of official discourse's use of this and related words such as wir [we] to create a sense of collective identity. In Example 4, the official usage is demonstrated in Ulbricht's opening words at the Fourth German Festival of Athletics and Sport, as recorded in the 1963 documentary Fest des Friedens und der Lebensfreude [Festival of Peace and Zest for Life].

\section{Example 4}

Die Stunden der Lebensfreude, der Schönheit und Besinnung, die wir hier verleben werden, und das tiefe Erlebnis unseres Nationalfestes mögen uns allen Ansporn sein, um die künftigen Aufgaben der Körperkultur und des Sportes für Vaterland, Frieden und Sozialismus erfolgreich zu lösen. Es lebe unsere DDR, das Vaterland aller guten Deutschen, es lebe die DDR, die Heimstätte und die Zukunft des deutschen Sportes, es lebe das IV. Deutsche Turn- und Sportfest, für Gesundheit und Lebensfreude, für Frieden und Sozialismus.

[May the hours of zest for life, beauty and reflection that we will experience here, and the deep experience of our national festival, encourage all of us to successfully take up the task of physical training and sport for the fatherland, peace and socialism. Long live our GDR, the fatherland of all good Germans, long live the GDR, the home and the 
future of German sport, long live the Fourth German Festival of Athletics and Sports, for health and zest for life, for peace and socialism.]

The documentary's commentary uses the word unser a further eight times and ends with this exhortation: Setz dir kein zu kleines Ziel und sei ganz ergeben, bei der Arbeit und dem Spiel, unserm neuen Leben [Don't set yourself a goal that's too small; be totally devoted, in work and play, to our new life]. Passages such as the following from the story Unser Herr Sportlehrer Stramm [Our Herr PE Teacher Stramm] strongly echo this usage:

Bei den Mädchen gibt unser Fräulein Heidenröslein Sport, und wir schauen sie gern an. Sie ist viel zahmer als unser Herr Stramm. Während wir Knaben nach seiner Pfeife flitzen müssen, tanzen die Mädchen meistens nach einer abgesägten Trommel. Fräulein Heidenröslein ruft dann immer in die Mädchen hinein, sie sollen sich schön strecken und ihre Brust hervorheben und die Arme und Beine elastisch schmeißen. Während unser Herr Stramm jeden Patzer bestraft, spricht Fräulein Heidenröslein wie eine sanfte Prinzessin zur schweren Wally, sie muß sich nicht fürchten, und sie wird den Bocksprung noch lernen. Der beste Bock im Springen ist der Lücht. Er sprang sogar über unseren Herrn Stramm und hat sich nur den Fuß verstaucht.

[The girls have our Fräulein Rosebud on the Heath for PE and we like watching her because she's much gentler than our Herr Ramrod. We have to run about like mad when he blows his whistle, but the girls get to dance while Fräulein Rosebud on the Heath bangs a little drum. Then she gets them to stretch, lift their chests and shake their arms and legs. Our Herr Ramrod tells us off for even the smallest mistake, but Fräulein Rose on the Heath is kindness itself. There's another fat girl, Wally, who's useless at leapfrog, but Fräulein Rosebud on the Heath tells her not to be scared and that she'll learn to do it eventually. The best frog at leaping is Lücht. Once he even jumped right over our Herr Ramrod and only twisted his ankle.]

It is in this context, too, that the fact that 17 of the stories contain unser [e] in their title should be viewed.

Many of the character names are connotative, and these also serve a satirical purpose. Jürgen and Andrea Schiewe (2000: 24) note the tendency of official discourse to rise to connotative heights through extremely expressive words and phrases. This is seen in Example 5, from Ulbricht's closing speech to the $6^{\text {th }}$ Party Congress in 1963.

\section{Example 5}

Jawohl, wir empfinden Freude und Glück, wenn wir beim Aufbau des Sozialismus bestimmte Hindernisse überwinden, wenn sich bei uns die Gemeinschaft festigt, wenn alle gemeinsam vorwärtsstreben, wenn die Genossen berichten, wie sie vorwärtsgekommen sind und was sie geschafft haben. Über Schwierigkeiten jammern? - Was soll das! Dazu haben wir heute keine Zeit, denn unser Blick ist nach vorn. Natürlich müssen wir die Schwierigkelten sehen, und wir können auch über die Schwierigkeiten schreiben. Aber unser Blick muß darauf gerichtet sein, wie die Schwierigkeiten überwunden werden. Das müssen wir schildern. Das zeichnet doch eben das Mitglied der Sozialistischen Einheitspartei, das Mitglied des Kollektivs, das Mitglied der Parteiorganisation aus. Die Genossen der Partei und des Kollektivs sehen die weitere Entwicklung voraus, sie verdrehen sich nicht den Hals, indem sie immer nur nach hinten schauen! 
(1963a: 3)

[Yes indeed, we experience pleasure and happiness when we overcome certain obstacles to the construction of socialism, when we push forwards together, when comrades report how they have made progress and what they have achieved. Complain about difficulties? Why would we? We haven't got any time to do that today, because we're setting our sights to the future. Naturally we must acknowledge the difficulties, and we write about them, too. But we must set our sights on how the difficulties can be overcome. We must describe this. That's what sets apart the member of the Socialist Unity Party, the member of the collective, the member of the party organisation. The comrades in the party and the collective look towards future developments, they don't turn their heads and only look behind!]

Against this background, the way connotative names stray into the ridiculous, in particular with Herr Rucksackbulle Max Speckmann [Herr Bull-in-a-Rucksack Max Speckmann], is another device by which Domma inverts official discourse.

It is important to consider Domma's reasons for bringing these two varieties of German into conflict. The effect is satirical, the pomposity of official discourse being repeatedly punctured as Ottokar blends it in comedically distorted form into his own everyday language. On the evidence of the position in GDR society of both Eulenspiegel and Domma himself, it can be concluded that, contrary to the normal intent of satire, this effect is not designed to undermine its target. Rather, it is designed to do the opposite: to build up the GDR. Censorship did not officially exist in the GDR, but nevertheless there were clear expectations of publishers. While Eulenspiegel was a satirical magazine, its continued existence relied on remaining within the boundaries of what the SED regarded as acceptable satire. For the SED, satire's purpose was to amuse and educate, not to subvert. Domma's satire follows this line. He was a member of the SED and, in his main occupation at Neues Deutschland, a representative of the establishment. He aimed to show adults that unthinkingly repeating the worst excesses of official discourse did not serve socialism's best interests. His purpose was to "ihnen den Spiegel vors Gesicht zu halten" [hold up a mirror to their faces] (1997: 33). The thoughtful, genuinely committed behaviour he wanted to encourage through his satire is made clear in an admiring report he wrote for Neues Deutschland about a teacher who made a well-received speech at an education conference:

Nach seiner Meinung besteht das Geheimnis seiner Erfolge darin, daß er nicht erst auf Weisungen von „oben" wartet, sondern gewissenhaft die Beschlüsse von Partei und Regierung studiert und schöpferisch für seine eigene Tätigkeit auswertet.

(Häuser, March 4, 1962: 6)

[In his opinion, the secret to his successes lies in the fact that he does not simply wait for instructions from "above" but painstakingly studies the resolutions of the government and the party and uses his own initiative to determine how they can be implemented in his particular context].

\section{Conventional approaches to translation vs. the challenges of multilingual humour}

The satirical effect of the Ottokar stories relies on the reader being able to recognise the clash between the two varieties of German. This would have been clear to the original readers. Today, however, new generations of native German speakers who are not familiar with the GDR and its official discourse are largely unaware of the stories' satirical intent. It was 
anticipated that conveying that intent in translation, which would require bringing the stories across an additional cultural and linguistic barrier, would be even more problematic. The translation of the stories was first approached through the lens of the most common translating scenario: the requirement to translate according to the commonly held expectations for conventional literary translation into English. In this context, adequately conveying the interplay between the stories' two varieties of German presented a significant methodological challenge.

While some publishers (for example, Pushkin Press) actively foreground and celebrate translation, it is most common in the Anglophone literary market for translated works to be expected to align with domestic notions of literature. On the one hand, there is evidence from translators' interactions with publishers' editors that the market is receptive to unfamiliar cultures (Paul 2009: 3). Vanessa Di Stefano's interviews with publishers at the London Book Fair also indicate that they expect a translator to give the new reader "the same" experience as that of the original reader, "what the source-text author gives to the source audience in their own language" (Di Stefano 2013). On the other hand, this openness to foreign culture is not the same as being open to foreign literary style. "Grace, beauty, colour and flavour must be captured" by the translator, but the resulting work "must also be capable of being understood by its new audience, and make sense on every level" (Paul 2009: 1, my emphasis). This means that publishers expect a translation that allows readers to explore difference yet at the same time remains within the parameters of the literary style with which they are familiar. In Lawrence Venuti's framing of the translator as an invisible agent, a translation is expected to be "transparent," with no "linguistic or stylistic peculiarities" (2004: 1). Such expectations mean that the translator cannot use the techniques, such as extensive glosses or footnotes, which would provide the additional explanation necessary to alert the reader to Ottokar's language use and its satirical effect. To do so would not "make sense" in the conventional understanding of Anglophone literary style. An impasse thus arises: explanation is necessary, but cannot be comfortably provided if the style of the translation is to remain acceptable. This will be illustrated with some examples of considerations regarding the use of glosses.

A linguistic feature of official discourse that Domma brings extensively into Ottokar's everyday German for satirical intent is the metaphor of struggle. The verb kämpfen [to battle/fight] and its related noun Kampf are particularly exploited in the story Unser Herr Pionierleiter Alfons [Our Herr Pioneer Leader Alfons]. As words, these can be translated. Indeed, this has a mildly amusing effect. The reader cannot help smiling at the idea that Ottokar and his peers are "battling" for good marks:

Liebe Pioniere! Der Kampf um gute Noten ist ein Höhepunkt unseres Pionierlebens. Wir befinden uns auf dem Vormarsch und marschieren zuversichtlich weiter. Im Sozialismus darf es keine Fünfen mehr geben. Das macht uns stolz und froh. Der Kampf um gute Noten ist eine feine Sache. Wir danken unseren Freunden, den Lehrern, und gehen mit Schwung an die Arbeit. Seid bereit!

[Dear Pioneers! Battling for good marks is a high point of our lives as Pioneers. We're gaining ground and we're marching on with confidence. Under socialism, nobody's allowed to get a low mark any more. That's something to feel proud and happy about. It's a good thing to battle to get good marks. We thank our friends, the teachers, and we're getting on with the task enthusiastically. Be prepared!]

However, conveying the satirical intent behind the creation of this zone of friction between official discourse and Ottokar's everyday German remains problematic. Following Clifford E. Landers, "where a discernible subtext is present, the translator's obligation is to choose words 
that best reproduce it" (2001: 127). Here, lexical choice alone does not convey the underlying satirising of those who unthinkingly repeated official discourse's ubiquitous use of militaristic language, the intent that Domma's original readers would have understood. Such allusions are essential to the text's satirical effect. By leaving them without explanation, the translator falls short of the requirement to give the new readers the same as the original readers received. A gloss (indicated in bold) was therefore added the first time the metaphor of struggle appears in this story:

Another important person is our Herr Pioneer Leader. He's called Alfons Spille, or just "Pleader the $7^{\text {th". }}$ That's his nickname, and it comes from him being the seventh Pioneer leader. In the olden days, that used to be called succession. He's not a real successor, though, because he doesn't have a throne or a golden coach or a family tomb, just a Jawa motorbike, a gold tooth and a young wife. She's a Pioneer leader in the other school, which means that she's battling alongside Pleader the 7th. It's important to keep battling, like it always says in the papers. Whenever she begins battling, Alfons tells us that we have to get our act together.

This addition alerts the reader to the fact that Ottokar is repeating official discourse. It thus gives a stronger sense that this sustained metaphor is not merely Ottokar "playing soldiers," as could be found in many conventional children's stories.

In a broader perspective, though, glossing creates a problem of accumulation. In looking progressively at all the forms of Domma's treatment of official discourse that would need to be glossed, it became clear that doing so would have a cumulative impact. This would not be so much quantitative as qualitative, making Ottokar's voice much more didactic than it is in the original stories. The target-text reader would gain a better sense of Ottokar's satirical target, but would not hear a voice that was "the same" as Ottokar's original voice. He speaks to readers who are already familiar with his world and can readily spot his allusions, not to readers who need explanations. Landers instructs the literary translator to "provide only as much information as can be conveyed without resort to artificiality" (2001: 80). This is achievable with an individual gloss. However, the cumulative effect of glosses would be precisely one of artificiality, creating the effect of Ottokar repeatedly making overt reference to his satirical targets, as these excerpts from early drafts of a conventional translation illustrate (glosses indicated in bold):

It's a bad thing for us children if the teacher family also gets our parents on its side. I've read about something called a balance of power with capitalism, and teachers and parents getting together creates a new one that you shouldn't underestimate.

The teacher family also stands together in inventing strict rules or convincing misguided pupils, like people who don't pull their weight in the community need to be convinced.

Then our Herr Headmaster nodded vigorously and spoke in a very high voice. He repeated what it says in the paper, that the most important thing of all was the potatoes and the Five Year Plan, and you shouldn't keep adding new things.

Under a conventional commission with its requirements for transparency, the translator is constantly seeking a balance between explanation and readability. An attempt to restore this balance was made by restricting the overall number of glosses in subsequent drafts, retaining only those that were quite short, that did not require parenthesis or an additional sentence and where it had been possible to keep reasonably close to Ottokar's original tone. Despite this 
paring down, however, the remaining glosses still produced a shift in tone. This was especially the case when, in order to create a link with official discourse, it was necessary to have Ottokar repeatedly refer explicitly to having read or heard something in a way that was not necessary in the original stories. These excerpts illustrate this effect (glosses indicated in bold):

Once my mother and father came home from a parents' meeting and kept going on about our Herr Class Teacher and a really strict teacher who I read about in the newspaper called Herr Makarenko, who definitely wasn't a lazy so-and-so.

But usually our dear teachers can't do anything about that, because all the important people say that they have to keep learning.

We boys, and the girls too, think more often now about how we're going to turn out. We're always hearing about so many great professions that it's very hard for us schoolchildren to know what the best ones are.

Sonja Schnitzler, the editor who wrote publishing house Eulenspiegel Verlag's submission for the print permit application for Der brave Schüler Ottokar, noted, "Ottokar kommentiert nicht" [Ottokar does not comment] (BStU-Archiv, Druck-Nr. 540/7/67). Yet glosses, and indeed other forms of explanatory intervention, can produce precisely this effect. The more the translator adds explanation, either in his/her own voice or in Ottokar's, in order to make the humour arising from the interplay of official discourse and Ottokar's everyday German clear to the reader in translation, the more that humour vanishes because, as the excerpts above illustrate, the explanation creates a shift in tone from ingeniously playful to tediously didactic.

While the expectations for a conventional literary translation were found to be incompatible with translating this particular example of multilingual humour into English, I felt that the mastery with which Domma creates his satire should not be allowed to remain unknown to contemporary Anglophone audiences. Producing a conventional translation is the translator's most regular task, but the exploratory nature of this work also allowed other approaches to be considered. Two contrasting directions were identified.

\section{Conveying multilingual humour through "thick" translation}

The first outcome of seeking to translate Der brave Schüler Ottokar conventionally was to highlight the need to consider adding extensive explanatory material. It had been seen that, without such material, contemporary readers would remain unaware of the existence of the stories' two varieties of German and the satirical intent with which they are brought into conflict. The next step, then, was to adopt a translational mode that gave the translator free rein to add explanation. The inspiration for this approach was provided by the concept of "thick" translation. This was proposed by Kwame Anthony Appiah by analogy with "thick description," a concept introduced by ethnographer Clifford Geertz to implement an "interpretive theory of culture" (1973: 3) that would allow finely nuanced distinctions to be drawn between societies. Appiah applies the "thick" approach to the translation of texts deeply embedded in another culture. Taking proverbs in his own Ghanaian language, he asks how it is possible to comprehend the implied meaning of a person's utterance if one does not fully share that person's frame of reference. In considering how very culturally-specific materials might be translated, Appiah suggests an approach similar to thick description, one 
that "seeks with its annotations and its accompanying glosses to locate the text in a rich cultural and linguistic context" (2012: 341).

An approach that encourages, indeed demands, the translator's intervention makes it possible to reveal to today's readers the stories' multilingual nature and, in turn, the satirical intent behind the harmlessly amusing exterior. The thick translation of the Ottokar stories begins with a translator's preface that includes these paragraphs:

On the surface, the stories are amusing children's tales. They can be enjoyed as such, and indeed Domma gradually came to be regarded in the GDR (and is remembered nostalgically today in united Germany) as a children's author. However, their primary intention initially was satirical. The name Ottokar derives from the Old High German "Odowakar," meaning quick-witted, and the character Ottokar lives up to his name. Appearing in an officially sanctioned magazine, the stories contributed to the official role of satire in the GDR, which was to turn the spotlight on people who were dogmatic and unthinking in following socialism, rather than being genuinely committed. In particular, Domma manipulates the themes and language of politics and the media ("official discourse") ingenuously in Ottokar's mouth to mock people who too readily parroted them.

As the stories unfold, the reader will notice an accumulation of the most persistent examples of Domma's satirising of the language of official discourse. Articles and politicians' speeches in Neues Deutschland and other official publications were full of devices such as repetition and redundancy, elevated and old-fashioned constructions and vocabulary, complex job titles and words conveying collective identity. Thus Ottokar constantly repeats people's full names, for example, he uses words (such as "likewise") that sound strange in a 12-year-old's mouth, he refers to "mother" and "father" rather than "mum" and "dad," he often uses the formal word "declare" where "said" would be expected, he creates complex combinations of name and job title (with many of the surnames being amusingly connotative) and repeatedly and redundantly uses "our" and "dear," two words beloved by the SED to create a sense of unity. In deliberate contrast with the seriousness with which the SED used such language to promote itself as progressive and the bastion of peace in central Europe, all of this takes place in comically banal or trivial contexts which Ottokar repeatedly and satirically stresses at the beginning of every story are "important." Further examples of the manipulation of official discourse that are less persistent are highlighted individually in a footnote the first time they appear.

The thickly-translated stories themselves are extensively footnoted (almost 300 in total) to draw readers' attention to particular features of the interplay of official discourse and everyday German. To return to the example of the metaphor of struggle, a footnote added to the translation of the story Unser Herr Pionierleiter Alfons [Our Herr Pioneer Leader Alfons] reads:

The source text uses the noun Kampf [battle/struggle/fight] and verb kämpfen seven times. Michael G. Clyne characterises this word as one of those that became a "frozen metaphor" in GDR official discourse. Kampf specifically referred to class struggle. Such fixed discourse was taught at school and contained in model texts. Ottokar's use of this metaphor in the mundane context of school marks satirises those who used it excessively or unthinkingly. Clyne, M. G. (1997). "The reconvergence of German after unification 
and its limits," in Clyne, M. G. (ed.), Undoing and Redoing Corpus Planning, Berlin: Mouton de Gruyter, pp. 117-142 (p. 127).

The use of a footnote also makes the reader aware, for example, that Ottokar's use of anaphora is not coincidental. In Die Gefahren unserer Dorflehrer [The Dangers Facing our Teachers in the Village], Ottokar uses the phrase Oder nehmen wir [Or let's take] four times. In the context of a trivial discussion about how teachers interact with local people, this is a clear indictment of those who punctuated their own conversations with the anaphora that was widely used in official discourse for rhetorical effect. A footnote explains this to readers today:

"Or let's take": the repetition of this phrase at the beginning of four paragraphs in this story satirises the anaphora commonly used in official discourse for rhetorical effect and, in turn, ordinary people who mimicked this usage unthinkingly.

In this way, the translation becomes "thick" with layers of explanation that function both individually and cumulatively to reveal the stories' manipulation of linguistic difference and friction. These layers need not consist only of written material. Valerie Pellatt advocates an understanding of the additions, or paratext, that characterise thick translation as "any material additional to, appended to or external to the core text which has functions of explaining, defining, instructing, or supporting, adding background information, or the relevant opinions and attitudes of scholars, translators and reviewers. Paratext is not necessarily written or verbal material. [...] non-verbal material is a powerful shaper of reactions and attitudes" (2013: 1). In this conceptualisation, thick translation can draw on resources such as photographs and audio and video clips. These materials can have a stronger impact than the written word. For example, the footnote above explaining that anaphora was heavily used in official discourse goes some way towards opening up to the reader the clash of two varieties of German, but adding a link to a video clip in which the reader can actually hear anaphora being used is even more effective. The final version of this footnote thus includes a link to Ulbricht's opening speech at the Fourth German Festival of Athletics and Sport, in which he uses the phrase Es lebe [Long live] three times in a single sentence:

"Or let's take": the repetition of this phrase at the beginning of four paragraphs in this story satirises the anaphora commonly used in official discourse for rhetorical effect and, in turn, ordinary people who mimicked this usage unthinkingly. This video clip of Walter Ulbricht speaking at the opening of the Fourth German Festival of Athletics and Sport demonstrates the use of anaphora, in this case the phrase Es lebe [Long live]: https://www.youtube.com/watch? $\mathrm{v}=\mathrm{x} 6 \mathrm{xEWm} 3 \mathrm{DUdk}$

While the reader may not be able to understand Ulbricht's actual words, the tone gives a powerful impression of the bombastic nature of official discourse. The satirical intent behind Ottokar's mis-placed use of rhetorical devices such as anaphora thus becomes clearer.

Multimodality can also extend to the mode of presentation of the entire thick translation "package." Merely pointing readers to resources such as video clips by providing URLs on the printed page seemed to fall short of the concept of thick translation in its fullest sense. When a translation is approached as a multimodal artefact, it naturally begins to extend beyond what the printed page can hold. A parallel web site containing the thick translation of the stories was thus developed (https://www.annotatedtranslationsblog.wordpress.com). In digital format, explanations can be presented directly alongside the text in pop-out boxes, rather than, as in traditional footnote format, at the bottom of the page. Thus, the stories' reliance on the interplay between two varieties of German for their effect is represented 
visually. The digital format also allows embedded photos and videos. The overall impact is more immediate than that of the printed version and thus, it can be argued, more conducive to replicating the original humour.

\section{Translating multilingual humour creatively}

The difficulties encountered with translating the Ottokar stories' multilingual humour conventionally also pointed in the direction of a creative approach. In their original German, the stories are playful and inventive. The thick approach explains the resulting humour. The translation, in effect, superimposes the humour on the stories from outside them. Yet originally, it emanated from within, from their playfulness and inventiveness. This suggested the need for a contrasting approach that allowed these features to be set free to inspire the stories' translation in a way that is as amusing for readers today as it was for Ottokar's readers in their time. Conceiving of the stories as a source of creative inspiration led to a translation that takes the form of a series of blog posts written by a $21^{\text {st }}$-century version of Ottokar (https://edtheblogger.wordpress.com).

The blog's author Ed is, like his begetter, a 12-year-old schoolboy. He, too, narrates his life at school, in his village and at home in everyday language that is (dis)ingenuously peppered with mis-replicated words and phrases from official discourse. That discourse, the second variety of English, is - as in the original stories - the language of politics and officialdom. As in the original stories, satire arises in the zone of friction between the two varieties of one language, the zone in which excessive and unthinking use of official discourse is revealed and punctured. Examples of Ed's manipulation of two characteristic features of official discourse — fixed collocations and anaphora — will demonstrate this effect in action.

British politicians favoured the fixed collocation "hard-working families" for some time, but it has been so mocked in recent years that they have become reluctant to use it. In a report in The Guardian in 2016, Sonia Sodha notes Theresa May's tendency to use "just about managing" families (Jams) instead. Both phrases are satirised in Ed's mouth. He misunderstands "hard-working families" and turns it into the malapropism "harm-working families," for example in the blog post What's so bad about daytime TV?:

Say you're watching Jeremy Kyle. You haven't even left your couch, but you're learning about ordinary harm-working families and how they're rising to the challenge of having loads of kids

Further satire arises when Ed creates his own fixed collocation by analogy with "hard[m]working families": "hard[m]-working teachers." Thus, in How do you deal with student teachers?:

So it's a big deal in our school when the student teachers come. Theirs even some blah about it on the school web site, like how exciting it is to be welcoming a new generation of harm-working teachers.

The idea that teachers could cause harm satirically inverts the very positive messages about teachers that politicians seek to convey, as seen in the statement in Example 6 made by Michael Gove during his time as Education Secretary. 


\section{Example 6}

I am fortunate as Education Secretary because we have the best generation of teachers ever in our classrooms - including the very best generation ever of young teachers - those who have entered our classrooms over the last few years.

Ed's mis-quoting and mis-application of "hard-working" serve to satirise both its excessive use in political discourse and the way in which, through that excessive use, it has become an object of derision. Ed taking up and inverting the phrase "just about managing" reinforces this effect. In The rents go to school, he comedically understands it literally:

Roxanne's mum, who has loads of kids (6 maybe? 8?), went on about how it's a real struggle for harm-working families and she can't buy her lot all the latest stuff, so it's an injustice. My dad talks like that, too. He says we're one of the Jams, but I really hope not, 'cos I like Marmite better.

Such misunderstandings give the lie to politicians' serious use of this phrase, as in Example 7, from Theresa May's first statement as Prime Minister in 2016.

\section{Example 7}

If you're one of those families, if you're just about managing, I want to address you directly. I know you're working around the clock, I know you're doing your best, and I know that sometimes life can be a struggle. The government I lead will be driven not by the interests of the privileged few, but by yours.

Anaphora remains a favourite rhetorical device of modern politicians. Example 8 is also taken from Theresa May's first statement as Prime Minister.

\section{Example 8}

If you're black, you're treated more harshly by the criminal justice system than if you're white.

If you're a white, working-class boy, you're less likely than anybody else in Britain to go to university.

If you're at a state school, you're less likely to reach the top professions than if you're educated privately.

If you're a woman, you will earn less than a man. If you suffer from mental health problems, there's not enough help to hand.

If you're young, you'll find it harder than ever before to own your own home.

Modern readers will recognise the anaphora in Ed's blog posts as echoing politicians' rhetoric. Among the original stories, anaphora is a particular feature of Unser liebes Weihnachtsfest [Our Dear Christmas Celebration]. In the blog-style translation, Our awesome Crimbo, the slang phrase "Here's the thing" serves well to echo this, building up from simply "Here's the thing" to finally "And a whole nother thing yet again": 
Here's the thing. This Crimbo stuff even makes a difference at school. We used to have a huge Christmas tree in the hall every year, which made the whole school smell great (yes, even the Year 11 boys' toilets...). [...]

And a whole nother thing: that special look brings special Crimbo lessons. Say our English teacher turns up. He's wearing the Christmas look (not to mention a Christmas jumper, uuurrgh) and we know there's a chance of some skiving. [...]

And a whole nother thing again: even our maths teacher Mr Young enters into the Crimbo spirit by giving us some themed sums. Like, I was in Lidl and I saw some mince pies being delivered. There were 20 crates, each with 50 boxes of mince pies in them. Each box of mince pies has six. How many mince pies were there altogether?

And a whole nother thing yet again: when our RE teacher turns up, he tells us about the origins of Christmas. Then, in a spirit of citizenship, he tells us about the origins of Diwali, and Hanukkah, and Ramadan, and so on.

A creative response that regards the source text as a point of departure draws both actively and subconsciously on a diverse and fluid range of sources. The illustrations above draw parallels between Ottokar and Ed in terms of their satirical manipulation of politicians' language. However, this should not be seen as suggesting that Ottokar is the only creative impetus for Ed's blogs. A response that branched out from the source text, rather than "translating" it in the sense of moving directly from one to the other, purposely allowed space for Ed to develop his own voice and for new forms of humour to emerge. For example, Ed repeatedly uses the phrase "elf and safety" in faux-naïve distortion of modern British officialdom's preoccupation with health and safety, a feature absent from GDR official discourse. His frequent use of youth argot (something that is not really a strong feature of Ottokar's use of language) also indicates a satirical target in addition to official discourse: he mocks those around him who conspicuously adopt this language and use it excessively. Further, there are traces in this creative response of sources completely unknown in Ottokar's world. For example, Ed's voice echoes that of Gregory, the wry schoolboy narrator in Jeff Kinney's Diary of a Wimpy Kid series. Like Gregory, Ed regards himself as intellectually superior to his peers, as in this excerpt from the blog post An endless supply of supply teachers:

Mr Leeder our headmaster says he's gonna start fighting the injustice of having to use so many supply teachers. He reckons that my crew should all become teachers. My bro Tom's up for it, 'cos he's too lazy to work more than three days a week. But even three days of dealing with Dumbo Dan and all the other losers like him would be too much for me.

When the source text is viewed merely as a starting point and brought into conversation with other sources of inspiration, the translation takes on a momentum of its own and the translator becomes a writer in his or her own right. Ottokar's humour still reaches today's readers, but it speaks through new frames of reference and discourse features that are as relevant to them as those of the GDR of the 1960s were to the stories' original readers.

\section{Conclusion: expanding the notion of "translation" in relation to multilingual humour}

The constraints imposed by the expectations of a conventional literary translation into English did not make it possible effectively to open up the multilingual humour in the Ottokar stories to readers today. However, adopting alternative strategies that allow the 
translator more flexibility did prove fruitful. The concept of a "thick" approach provided the impetus for adding all the explanation necessary to alert the reader to the clash of two varieties of German in the stories, and the resulting satire. It also enriched the final translation compared with a conventional literary translation, both by making the explanatory material multimodal and by presenting the translation itself multimodally. In contrast, the creative approach did not seek to explain the original humour, but rather to re-vision the heterolinguality of the original stories in the context with which today's Anglophone readers are familiar. The outcome was a translation that offers new multilingual humour in its own right.

The two possible ways of approaching the Ottokar stories pursued here raise the slippery question of what actually constitutes a "translation." To those who expect a translation to provide "the same" as the original text, the addition of explanatory features or the bringing of the text into the 21 st century would not constitute a translation, but rather an exegetical text or an adaptation respectively. However, translation scholarship has long been influenced by Gideon Toury's call for a shift away from restrictive definitions. Translations are, Toury proposes, "any target-language utterance which is presented or regarded as such within the target culture, on whatever grounds" (1995: 32). This work demonstrated that the translation of multilingual humour is one area of translation where it is helpful, even necessary, to expand the notion of "translation." To be unwilling or unable to go beyond the narrow definition implied by the expectations of a conventional literary translation would have meant that contemporary Anglophone readers would have remained unaware of the real intent and significance of the Ottokar stories. If translation's role is to open up a text to the reader, then the thick and creative versions can certainly be regarded as translations. Indeed, through making the paratextual interventions and through bringing Ottokar into the 21 st century, the source text has been "translated" far more extensively and deeply than was possible in the conventional literary translation context, where the product is usually taken to be a translation. Ultimately, though, it is not problematic if readers regard the thick and creative versions as something other than translations. The primary concern when making these translations was not so much how they are perceived as the effect they have.

A welcome development in the translation of multilingual humour would be further attempts to apply to other languages, language varieties and genres the opportunities for pursuing translational strategies that privilege effect over form. The successful translation of such humour relies on opening up for the reader the zone where two or more languages, or distinct varieties of the same language, come into friction. If this is to be achieved, the translator must be granted the freedom to step beyond the notion that a translation should be "the same" as the original. The work undertaken here suggests that alternative strategies that draw on a broader understanding of translation can serve well to bring heterolingual humorous texts into new linguistic contexts.

\section{References}

Appiah, K. A. (2012). 'Thick translation', in Venuti, L. (ed.), The Translation Studies Reader, $3^{\text {rd }}$ edn, Abingdon: Routledge, pp. 331-343.

Bergmann, C. (1996). 'Parteisprache und Parteidenken: Zum Sprachgebrauch des ZK der SED', in Lerchner, H. (ed.), Sprachgebrauch im Wandel: Anmerkungen zur Kommunikationskultur in der DDR vor und nach der Wende, Peter Lang: Frankfurt, pp. $65-84$. 
Clyne, M. G. (1997). 'The reconvergence of German after unification and its limits', in Clyne, M. G. (ed.), Undoing and Redoing Corpus Planning, Berlin: Mouton de Gruyter, pp. 117142.

Corrius, M. \& Zabalbeascoa, P. (2011). 'Language variation in source texts and their translations: The case of L3 in film translation'. Target 23 (1), pp. 113-130.

Di Stefano, V. (2013). Personal email, November 17.

Domma, O. (1967). Der brave Schüler Ottokar. Berlin: Eulenspiegel Verlag.

Domma, O. (1997). Ottokar gibt Auskunft. Berlin: Eulenspiegel Verlag.

Ebert, F. (1964). 'Die technologische Revolution ist ohne die Frauen nicht möglich'. June 27. Neues Deutschland.

Geertz, C. (1973). The Interpretation of Cultures: Selected Essays By Clifford Geertz. New York: Basic Books.

Gove, M. (2013). 'Michael Gove speaks about the importance of teaching'. September 5. Retrieved March 16, 2018 from https://www.gov.uk/government/speeches/michael-govespeaks-about-the-importance-of-teaching.

Häuser, O. (1962). 'Quell des lebendigen Lehrens und Lernens'. March 4. Neues Deutschland.

Landers, C. E. (2001). Literary Translation: A Practical Guide. Clevedon: Multilingual Matters.

May, T. (2016). 'Statement from the new Prime Minister Theresa May'. July 13. Retrieved January 21, 2018 from https://www.gov.uk/government/speeches/statement-from-thenew-prime-minister-theresa-may.

No author (1963). 'Gruß aus Moskau'. January 1. Berliner Zeitung.

Paul, G. (ed.) (2009). Translation in Practice. London: Dalkey Archive Press.

Pellatt, V. (ed.) (2013). Text, Extratext, Metatext and Paratext in Translation. Newcastle upon Tyne: Cambridge Scholars Publishing.

PROGRESS Film-Verleih (n.d.). Retrieved April 29, 2018 from http://www.progressfilm.de/fest-des-friedens-und-der-lebensfreude.html.

Rodden, J. (2002). Painting the Little Red Schoolhouse: A History of Eastern German Education, 1945-1995. Oxford: Oxford University Press.

Sodha, S. (2016). 'Will Theresa May's 'just about managing families' fall for the rhetoric?'. November 21. The Guardian. Retrieved February 16, 2018 from https://www.theguardian.com/commentisfree/2016/nov/21/theresa-may-jams-rhetoricjust-managing-families-autumn-statement.

Schiewe, A. \& Schiewe, J. (2000). Witzkultur in der DDR: Ein Beitrag zur Sprachkritik. Göttingen: Vandenhoeck \& Ruprecht.

Schnitzler, S. (1967). BStU-Archiv, Druck-Nr. 540/7/67.

Stevenson, P. (2002). Language and German Disunity: A Sociolinguistic History of East and West in Germany, 1945-2000. Oxford: Oxford University Press.

Toury, G. (1995). Descriptive Translation Studies and Beyond. Amsterdam: John Benjamins Publishing Company.

Ulbricht, W. (1963a). 'Schlußwort des Genossen Walter Ulbricht'. 20 January. Neues Deutschland.

Ulbricht, W. (1963b). Speech at the opening of the Fourth German Festival of Athletics and Sport. Retrieved April 5, 2018 from https://www.youtube.com/watch?v=x6xEWm3DUdk.

Venuti, L. (2014). The Translator's Invisibility: A History of Translation. London: Routledge.

Wolle, S. (2011). Aufbruch nach Utopia: Alltag und Herrschaft in der DDR 1961-1971. Berlin: Ch. Links Verlag.

Young, J. W. (1991). Totalitarian Language: Orwell's Newspeak and its Nazi and Communist Antecedents. London: University Press of Virginia. 